\title{
COVID-19 presenting as neutropenic fever
}

\author{
Hunter C. Spencer ${ }^{1}$ (iD) $\cdot$ Riana Wurzburger ${ }^{1}$
}

Received: 8 May 2020 / Accepted: 3 June 2020 / Published online: 13 June 2020

(C) Springer-Verlag GmbH Germany, part of Springer Nature 2020

\section{Dear Editor,}

We describe successful recovery from mild COVID-19 in a patient with pancytopenia presenting with neutropenic fever. While lymphopenia has been reported as a common finding in COVID-19, particularly in severe cases, neutropenia has been rarely reported. A case series of over 1000 patients in China observed $83 \%$ of patients had lymphopenia but did not report neutropenia, defined as absolute neutrophil count less than 1500 per cubic mm [1]. A 51-yearold man with NK-cell large granular lymphocytic leukemia complicated by pancytopenia presented with acute fever and cough and was subsequently found to be neutropenic. The patient had stable pancytopenia on a chronic regimen of cyclosporine with no recent bleeding, transfusions, or neutropenia. His exam was notable for a peak temperature of $39.4{ }^{\circ} \mathrm{C}$, bilateral crackles but normal oxygen saturation while breathing room air. Chest $\mathrm{x}$-ray showed bilateral interstitial infiltrate. His labs at presentation were notable for pancytopenia, with mild trilineage decrease compared with baseline (Table 1). His initial absolute neutrophil count (ANC) was 550 per cubic mm, a lifetime nadir. COVID19 was diagnosed by nasopharyngeal swab with RT-PCR positive for SARS-CoV-2. Negative microbiologic tests included blood cultures, urine culture, and urine antigens for pneumococcus and legionella. He was treated with cefepime, in accordance with guideline recommendations for neutropenic fever, and azithromycin based on initial concern for atypical bacterial community-acquired pneumonia [2]. Cyclosporine was held throughout the admission and resumed after his first hematology follow-up visit. He was treated with two doses filgrastim (Table 1). Hospital course was uncomplicated and similar to mild courses described in large case series of COVID-19 [1, 3, 4]. In fact, his time to resolution of dyspnea, time to resolution of fever, and hospital duration were on the low end of the described range (Table 1). Filgrastim was used with the expected neutrophil response and without apparent adverse events, although caution should be employed as endogenous granulocyte stimulating factor has been associated with COVID-19-related cytokine storm [5]. As COVID-19 spreads among neutropenic patients, further observations regarding the clinical course and response to emerging therapies are necessary to understand the host-virus interaction in this high-risk group.
Hunter C. Spencer

spencerh@ohsu.edu

1 Department of Medicine, Oregon Health \& Science University, 7310, 3245 SW Pavilion Loop, Portland, OR 97239, USA 
Table 1 Trend in fever and complete blood count parameters. "+" indicates the day that COVID-19 RT-PCR became positive. "*" indicates day a dose of filgrastim was administered. "Baseline" reflects labs acquired at the most recent outpatient visit, 3 weeks prior to presentation. "Follow up" denotes labs acquired 2 weeks post-discharge

\begin{tabular}{|c|c|c|c|c|c|c|c|c|c|c|}
\hline & Baseline & $\begin{array}{l}\text { Day of } \\
\text { admission }\end{array}$ & $\begin{array}{l}\text { Hospital } \\
\text { day } 1^{+*}\end{array}$ & $\begin{array}{l}\text { Hospital } \\
\text { day } 2\end{array}$ & $\begin{array}{l}\text { Hospital } \\
\text { day } 3\end{array}$ & $\begin{array}{l}\text { Hospital } \\
\text { day } 4\end{array}$ & $\begin{array}{l}\text { Hospital } \\
\text { day } 5 *\end{array}$ & $\begin{array}{l}\text { Hospital } \\
\text { day\#6 }\end{array}$ & $\begin{array}{l}\text { Day of } \\
\text { discharge }\end{array}$ & $\begin{array}{l}\text { Follow } \\
\text { up }\end{array}$ \\
\hline $\operatorname{Tmax}\left({ }^{\circ} \mathrm{C}\right)$ & -- & 38.0 & 38.7 & 38.6 & 39.4 & 38.8 & 39.2 & 37.4 & 37.1 & -- \\
\hline $\begin{array}{l}\text { White cell count (per } \\
\mathrm{mm}^{3} \text { ) }\end{array}$ & 3440 & 1900 & 2010 & 4570 & 5140 & 4330 & 2450 & 5000 & -- & 2680 \\
\hline $\begin{array}{l}\text { Absolute neutrophil count } \\
\left(\text { per } \mathrm{mm}^{3}\right)\end{array}$ & 1240 & 550 & 610 & 3250 & 3760 & 2900 & 1240 & 3010 & -- & 560 \\
\hline $\begin{array}{l}\text { Total lymphocytes (per } \\
\mathrm{mm}^{3} \text { ) }\end{array}$ & 1780 & 580 & 1140 & 890 & 1110 & 1120 & 930 & 990 & -- & 1700 \\
\hline Hemoglobin (g/deciliter) & 10.9 & 10.5 & 9.4 & 10.5 & 10.5 & 10.6 & 10.3 & 9.8 & -- & 8.6 \\
\hline Platelets (per $\mathrm{mm}^{3}$ ) & 83,000 & 56,000 & 44,000 & 48,000 & 42,000 & 43,000 & 44,000 & 38,000 & -- & 22,000 \\
\hline
\end{tabular}

\section{Compliance with ethical standards}

Conflict of interest The authors declare that they have no conflict of interest.

Ethical approval All procedures performed in studies involving human participants were in accordance with the ethical standards of the institutional and/or national research committee and with the 1964 Helsinki declaration and its later amendments or comparable ethical standards.

Informed consent Informed consent was obtained from the individual participant included in the study.

\section{References}

1. Guan W, Ni Z, Hu Y, Liang WH, Ou CQ, He JX, Liu L, Shan H, Lei CL, Hui DSC, du B, Li LJ, Zeng G, Yuen KY, Chen RC, Tang CL, Wang T, Chen PY, Xiang J, Li SY, Wang JL, Liang ZJ, Peng YX, Wei L, Liu Y, Hu YH, Peng P, Wang JM, Liu JY, Chen Z, Li G, Zheng ZJ, Qiu SQ, Luo J, Ye CJ, Zhu SY, Zhong NS, China Medical Treatment Expert Group for Covid-19 (2020) Clinical characteristics of coronavirus disease 2019 in China. N Engl J Med 382:1708-1720. https://doi.org/10.1056/NEJMoa20020323
2. Freifeld AG, Bow EJ, Sepkowitz KA, Boeckh MJ, Ito JI, Mullen CA, Raad II, Rolston KV, Young J-AH, Wingard JR (2011) Clinical practice guideline for the use of antimicrobial agents in neutropenic patients with cancer: 2010 update by the Infectious Diseases Society of America. Clin Infect Dis 52(4):e56-e93. https://doi.org/10.1093/ $\mathrm{cid} / \mathrm{cir} 0732$

3. Zhou F, Yu T, Du R et al (2020) Clinical course and risk factors for mortality of adult inpatients with COVID-19 in Wuhan China: a retrospective cohort study. Lancet. 395(10229):1054-1062. https:// doi.org/10.1016/S0140-6736(20)30566-34

4. Wu C, Chen X, Cai Y, Xia J', Zhou X, Xu S, Huang H, Zhang L, Zhou X, du C, Zhang Y, Song J, Wang S, Chao Y, Yang Z, Xu J, Zhou X, Chen D, Xiong W, Xu L, Zhou F, Jiang J, Bai C, Zheng J, Song Y (2020) Risk factors associated with acute respiratory distress syndrome and death in patients with coronavirus disease 2019 pneumonia in Wuhan, China. JAMA Intern Med. https://doi.org/10.1001/ jamainternmed.2020.09945

5. Huang C, Wang Y, Li X, Ren L, Zhao J, Hu Y, Zhang L, Fan G, Xu J, Gu X, Cheng Z (2020) Clinical features of patients infected with 2019 novel coronavirus in Wuhan, China. Lancet 395(10223):497506

Publisher's note Springer Nature remains neutral with regard to jurisdictional claims in published maps and institutional affiliations. 